\title{
Inhaler use in adolescents and adults with self-reported physician-diagnosed asthma, bronchitis, or emphysema in the city of Pelotas, Brazil*
}

\author{
Uso de inaladores na população de adolescentes e adultos \\ com diagnóstico médico autorreferido de asma, \\ bronquite ou enfisema em Pelotas, RS \\ Paula Duarte de Oliveira, Ana Maria Baptista Menezes, \\ Andréa Dâmaso Bertoldi, Fernando César Wehrmeister
}

\begin{abstract}
Objective: To evaluate the characteristics of users of inhalers and the prevalence of inhaler use among adolescents and adults with self-reported physician-diagnosed asthma, bronchitis, or emphysema. Methods: A populationbased study conducted in the city of Pelotas, Brazil, involving 3,670 subjects $\geq 10$ years of age, evaluated with a questionnaire. Results: Approximately 10\% of the sample reported at least one of the respiratory diseases studied. Among those individuals, 59\% reported respiratory symptoms in the last year, and, of those, only half reported using inhalers. The use of inhalers differed significantly by socioeconomic status (39\% and 61\% for the lowest and the highest, respectively, $p=0.01$ ). The frequency of inhaler use did not differ by gender or age. Among the individuals reporting emphysema and inhaler use, the use of the bronchodilator-corticosteroid combination was more common than was that of a bronchodilator alone. Only among the individuals reporting physiciandiagnosed asthma and current symptoms was the proportion of inhaler users higher than 50\%. Conclusions: In our sample, inhalers were underutilized, and the type of medication used by the individuals who reported emphysema does not seem to be in accordance with the consensus recommendations.
\end{abstract}

Keywords: Metered dose inhalers; Asthma; Pulmonary disease, chronic obstructive; Bronchitis; Emphysema; Dry powder inhalers.

\section{Resumo}

Objetivo: Avaliar as características dos usuários de dispositivos inalatórios e a frequência de uso desses em adolescentes e adultos com diagnóstico médico autorreferido de asma, bronquite ou enfisema. Métodos: Estudo de base populacional realizado em Pelotas, RS, incluindo 3.670 indivíduos com idade $\geq 10$ anos, avaliados com um questionário. Resultados: Aproximadamente 10\% da amostra referiram pelo menos uma das doenças respiratórias investigadas. Entre esses, 59\% apresentaram sintomas respiratórios no último ano, e, desses, apenas metade usou inaladores. 0 uso de inaladores diferiu significativamente de acordo com o nível socioeconômico (39\% e 61\% entre mais pobres e mais ricos, respectivamente; $p=0,01$ ). Não houve diferença na frequência de uso de inaladores por sexo ou idade. Entre indivíduos com enfisema, o uso da combinação broncodilatador + corticoide inalatório foi mais frequente que o uso isolado de broncodilatador. Somente entre os indivíduos que referiram diagnóstico médico de asma e sintomas atuais, a proporção de uso de inaladores foi maior que 50\%. Conclusões: Em nossa amostra, os inaladores foram subutilizados, e o tipo de medicamento usado por aqueles que referiram enfisema parece não estar de acordo com o preconizado em consensos sobre essa doença. Descritores: Inaladores dosimetrados; Asma; Doença pulmonar obstrutiva crônica; Bronquite; Enfisema; Inaladores de pó seco.

\footnotetext{
* Study carried out under the auspices of the Graduate Program in Epidemiology, Federal University of Pelotas, Pelotas, Brazil. Correspondence to: Ana Maria Baptista Menezes. Rua Marechal Deodoro, 1160, Centro, CEP 96020-220, Pelotas, RS, Brasil. Tel. 5553 3284-1300. E-mail: anamene@terra.com.br Financial support: None.

Submitted: 8 January 2013. Accepted, after review: 4 March 2013.
} 


\section{Introduction}

Inadequate management of asthma and COPD is detrimental to the quality of life of patients and generates avoidable costs to the health care system. ${ }^{(1,2)}$ Among the available drugs, those administered via inhaler devices constitute the treatment of choice for the control of asthma and COPD and are indicated for all such patients, except for those who have cognitive deficits or who do not adapt to inhaler devices and opt for a nebulizer. ${ }^{(1,2)}$

In Brazil, the number of hospitalizations for asthma in adults dropped in the last decade; however, asthma is still among the leading causes of hospitalization and, in 2011 , was the fourth leading cause of hospitalization among patients of all ages. ${ }^{(1)}$ Another leading cause of hospitalization is COPD, and the burden of the disease on the health care system is expected to increase in the coming years. ${ }^{(2,3)}$ By 2020, COPD is expected to have become the fifth leading cause of disability-adjusted life years. ${ }^{(3)}$

Although the worsening of symptoms and the frequency of exacerbations do not always indicate disease progression, they can indicate poor treatment adherence or inability to use inhalers, ${ }^{(4)}$ which is aggravated by the fact that many health professionals do not have enough knowledge to instruct patients on how to use inhaler devices correctly. ${ }^{(5)}$ According to data from the Projeto Latino-Americano de Investigação em Obstrução Pulmonar (PLATINO, Latin-American Project for the Investigation of Pulmonary Obstruction), the proportion of patients receiving inhaled medication is smaller than expected, and the form of administration and frequency of use are not in accordance with the recommendations. ${ }^{(6)}$ Regarding asthma, despite advances in asthma control, the proportion of patients seeking emergency room treatment because of poor adherence to inhaled corticosteroid (IC) therapy is high..$^{(7,8)}$

Studies investigating inhaler use among asthma and COPD patients are needed in order to identify shortcomings and, indirectly, assess the quality of the health care provided to such patients. However, a recent review of the literature revealed no population-based studies conducted in Brazil and primarily focusing on inhaler use.

In this scenario, the objective of the present study was to describe inhaler use among individuals with self-reported physician-diagnosed asthma, bronchitis, emphysema, or any combination of the three in the city of Pelotas, Brazil.

\section{Methods}

This was a descriptive, cross-sectional, population-based study conducted in the city of Pelotas between February and June of 2012 as part of a large population health survey. The strategy used is designated "research consortium", ${ }^{(9)}$ whereby several researchers combine their questionnaires into a single instrument, thus streamlining data collection and reducing costs. The target population consisted of individuals aged 10 years or older.

Sampling was conducted in two stages: in the first stage, 130 of the 495 census sectors in the urban area were systematically selected, the probability being proportional to the number of households; because the number of households in each census sector had last been determined in 2010 by the Brazilian Institute of Geography and Statistics, we mapped the households in each sector before starting the fieldwork; in the second stage, the number of selected households was defined by the growth of the sector in relation to the 2010 count, and an average of 13 households were selected in each sector, a total of 1,722 households having been selected.

All of the residents that were in the target age group were invited to participate, institutionalized or mentally disabled individuals being excluded. Standardized questionnaires addressing demographic, socioeconomic, behavioral, and health aspects were administered by trained interviewers.

The use of inhalers was evaluated only in those who reported having any of the following physician-diagnosed respiratory diseases: asthma/ wheezy bronchitis, bronchitis, emphysema, or any combination of the three. The adolescents (i.e., those in the 10-19 year age bracket) were asked only about asthma/wheezy bronchitis.

Whenever an individual gave at least one affirmative answer, the individual was asked about symptoms and inhaler use. We determined the presence of symptoms in the previous year by asking the following question: "Since (month) of last year, have you had attacks or symptoms of this/these disease(s), such as wheezing, cough, or breathlessness? (yes/no)". The interviewers were instructed to replace the word "month" with the corresponding month in the 12-month 
recollection period. For the same period, we asked about nebulizer use (yes/no) and inhaler use (yes/no), using the terms "pump, dry powder inhaler, or any other medication for inhalation/ aspiration".

Those who had used an inhaler were asked to provide the package for collection of the name(s) of the drug(s). Those who did not have the package were shown a catalog of drugs so that they could indicate the drug or drugs that they had used. The drugs were categorized by type of inhaler, i.e., metered dose inhaler (MDI) or dry powder inhaler (DPI), and type of medication, i.e., bronchodilator (BD), 1C, or a combination of both $(\mathrm{BD}+1 \mathrm{C})$.

Those who reported not having used an inhaler were asked why they had not, the reasons being grouped into the following categories: belief that there was no need to use an inhaler; lack of financial resources to purchase an inhaler; lack of physician recommendation; difficulty using inhalers; and fear of side effects.

Of the demographic, socioeconomic, and behavioral variables collected, the following were used in the present study: gender; age; years of completed schooling; the Indicador Econômico Nacional (IEN, National Economic Indicator), ${ }^{(10)}$ categorized into quintiles (in ascending order by socioeconomic status, from the lowest to the highest); and smoking status, i.e., never smoker, smoker (having smoked at least one cigarette per day for more than one month), and former smoker (having smoked no cigarettes for more than one month).

Data were collected through netbooks running the Pendragon Forms 6.1 software (Pendragon Software Corporation, Libertyville, IL, USA) with the questionnaire, and the interviews were synchronized weekly to the database. For quality control, 10\% of the participants answered 14 of the questions again in a visit that took place within up to 15 days after the interview. The question regarding the diagnosis of asthma/wheezy bronchitis showed a kappa statistic of 0.65 .

The findings were expressed as absolute and relative frequencies, with the respective 95\% Cls. We used the chi-square test for heterogeneity for nominal categorical variables and the chi-square test for linear trend for ordinal categorical variables. Data analysis was performed with the STATA statistical software package, version 12.0 (Stata Corp., College Station, TX, USA).
The participants or their legal guardians gave written informed consent, and the study project was approved by the Research Ethics Committee of the Federal University of Pelotas School of Medicine, located in the city of Pelotas, Brazil, on December 1, 2011 (Protocol no. 77/11).

\section{Results}

Of the 4,168 eligible individuals, 3,670 were included in the study sample $(12.1 \%$ having been lost to follow-up or having declined to participate). Of those, 402 (11\%) reported having been diagnosed with at least one of the respiratory diseases under study. The overall prevalence of asthma was 7.5\% (95\% Cl, 6.6-8.3), the overall prevalence of bronchitis was $6.1 \%$ (95\% Cl, 5.2-6.9), and the overall prevalence of emphysema was $1.6 \%(95 \% \mathrm{Cl}, 1.2-2.1$; Table 1$)$. The characteristics of the study sample and the prevalence of each disease (according to the demographic characteristics, socioeconomic characteristics, and smoking status) are shown in Table 1.

Of the 402 individuals who reported having a respiratory disease, 146 (36.2\%; 95\% Cl, 31.4-40.9) had used an inhaler device in the previous year, and 237 (59\%) reported having had symptoms in the same period. Of the 237 symptomatic individuals, 120 (50.6\%; 95\% Cl, 44.2-57.0) reported having used an inhaler. Of those who remained asymptomatic, $25(15.2 \% ; 95 \% \mathrm{Cl}$, 9.7-20.8) reported having used an inhaler.

Figure 1 shows the distribution of inhaler users by IEN quintile among the individuals who reported having had respiratory symptoms in the previous year. Although the 95\% Cls overlapped, a higher IEN translated to a higher frequency of inhaler use, a linear trend being observed $(p=0.010)$. Similar results were obtained with the use of other socioeconomic indicators, such as the Brazilian Association of Survey Firms classification ${ }^{(11)}$ (data not shown). The frequency of inhaler use did not differ by gender or age in the sample as a whole or in the symptomatic individuals.

The proportion of individuals who had not used any type of inhaler was higher than 50\% among those who reported having bronchitis or emphysema. Among those who had used an inhaler in the previous year, MDls were the most widely used by patients with asthma or bronchitis, whereas there was no difference between MD1 
Table 1 - Description of the sample and prevalence of self-reported physician-diagnosed respiratory disease, Pelotas, Brazil, 2012.

\begin{tabular}{|c|c|c|c|c|}
\hline \multirow[t]{3}{*}{ Variable } & \multirow{3}{*}{$\begin{array}{l}\text { Sample } \\
\text { n (\%) }\end{array}$} & \multicolumn{3}{|c|}{ Respiratory disease } \\
\hline & & Asthma & Bronchitis & Emphysema \\
\hline & & $(n=274)$ & $(n=178)$ & $(n=47)$ \\
\hline Gender & & $p=0.063$ & $p=0.110$ & $p=0.838$ \\
\hline Male & $1,562(42.6)$ & $6.5(5.3-7.8)$ & $5.2(4.0-6.5)$ & $1.7(0.9-2.4)$ \\
\hline Female & 2,108 (57.4) & $8.2(7.0-9.3)$ & 6.7 (5.5-7.8) & $1.6(1.0-2.2)$ \\
\hline Age & & $p<0.001^{* *}$ & $p=0.957^{* *}$ & $p<0.001^{* *}$ \\
\hline $10-19^{a}$ & $743(20.3)$ & $13.3(10.8-15.8)$ & - & - \\
\hline $20-29$ & 612 (16.7) & 6.7 (4.7-8.7) & $6.2(4.3-8.1)$ & - \\
\hline $30-39$ & $540(14.7)$ & $7.0(4.9-9.2)$ & $5.7(3.8-7.7)$ & $0.4(0.0-0.9)$ \\
\hline $40-49$ & 595 (16.2) & $5.4(3.6-7.2)$ & $5.9(4.0-7.8)$ & $0.8(0.1-1.6)$ \\
\hline $50-59$ & $514(14.0)$ & $5.8(3.8-7.9)$ & $6.8(4.6-9.0)$ & $2.3(1.0-3.6)$ \\
\hline 60 or older & $666(18.2)$ & $5.1(3.4-6.8)$ & $5.9(4.1-7.6)$ & $4.2(2.7-5.7)$ \\
\hline Schooling ${ }^{b}$, years & & $p=0.031^{* *}$ & $p=0.061^{* *}$ & $p<0.001^{* * *}$ \\
\hline Up to 4 & $651(17.8)$ & $9.2(7.0-11.4)$ & $8.6(6.2-11.0)$ & $4.2(2.5-5.9)$ \\
\hline $5-9$ & $1,313(35.8)$ & 7.3 (5.9-8.7) & $5.2(3.7-6.7)$ & $1.5(0.7-2.3)$ \\
\hline $10-14$ & 1,217 (33.2) & $7.6(6.2-9.1)$ & $6.1(4.7-7.6)$ & $1.1(0.4-1.7)$ \\
\hline 15 or more & 486 (13.3) & $5.1(3.2-7.1)$ & $5.0(3.0-6.9)$ & $0.2(0.0-0.6)$ \\
\hline $\mathrm{IEN}^{\mathrm{c}}$, quintiles & & $p=0.094^{* *}$ & $p=0.477^{* *}$ & $p=0.010^{* *}$ \\
\hline 1st (the poorest) & $735(20.2)$ & $8.0(6.1-10.0)$ & $7.0(4.9-9.0)$ & $2.4(1.1-3.6)$ \\
\hline 2nd & 723 (19.9) & $7.9(6.0-9.9)$ & $6.5(4.5-8.6)$ & $2.2(1.0-3.4)$ \\
\hline $3 r d$ & $732(20.1)$ & $7.7(5.7-9.6)$ & $4.6(2.9-6.3)$ & $1.4(0.4-2.3)$ \\
\hline 4th & 720 (19.8) & $8.6(6.6-10.7)$ & $6.2(4.3-8.2)$ & $1.4(0.4-2.3)$ \\
\hline 5th (the richest) & 727 (20.0) & $5.1(3.5-6.7)$ & $6.0(4.1-8.0)$ & $0.7(0.0-1.4)$ \\
\hline Smoking status & & $p=0.726$ & $p=0.001$ & $p=0.001$ \\
\hline Never smoker & 2,397 (65.3) & $7.7(6.7-8.8)$ & $5.1(4.1-6.2)$ & $0.9(0.4-1.3)$ \\
\hline Former smoker & $634(17.3)$ & $6.9(5.0-8.9)$ & $5.5(3.7-7.2)$ & $2.2(1.1-3.4)$ \\
\hline Smoker & $639(17.4)$ & $7.0(5.1-9.0)$ & $9.4(7.1-11.7)$ & $3.0(1.6-4.3)$ \\
\hline Total & $3,670(100)$ & $7.5(6.6-8.3)$ & $6.1(5.2-6.9)$ & $1.6(1.2-2.1)$ \\
\hline
\end{tabular}

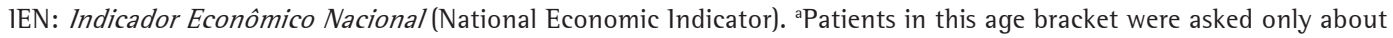
asthma or wheezy bronchitis. b3 observations ignored. c33 observations ignored. *Chi-square test for heterogeneity, except where otherwise indicated. ${ }^{* *}$ Chi-square test for linear trend.

use and DPl use among those with emphysema (Figure 2).

Regarding the drug regimen used by the symptomatic individuals, Figure 3 shows the distribution of BD use and BD + IC use. Only among those reporting emphysema was the proportion of $\mathrm{BD}+\mathrm{IC}$ users higher than was that of BD-only users. Two of the respondents did not know the type of inhaler that they had used.

Of the 117 individuals who reported that they had had symptoms and had not used any type of inhaler, 38\% reported nebulizer use. The most common reasons for not using an inhaler were "belief that there was no need to use an inhaler" $(60.7 \%)$ and "lack of physician recommendation" (23.9\%), followed by "fear of side effects", "lack of financial resources to purchase an inhaler", and "difficulty using inhalers".

\section{Discussion}

Inhaler devices are of great importance in the treatment of respiratory diseases, having advantages such as direct deposition of the drug in the target organ and rapid effect in reducing symptoms. ${ }^{(12)}$ The objective of the present study was to describe inhaler use among individuals who gave affirmative answers to questions regarding asthma, bronchitis, and emphysema. It is of note that this cannot be considered the real prevalence of inhaler use in the population, because inhalers can be indicated for other conditions or used as self-medication. Another limitation of the present study is the use of self-reported diagnosis, 
which can lead to information bias. However, unlike other studies conducted in Brazil and investigating inhaler use-most of which evaluated samples of individuals selected from among those being treated at primary health care clinics or hospitals-our study evaluated a sample that was representative of the general population.

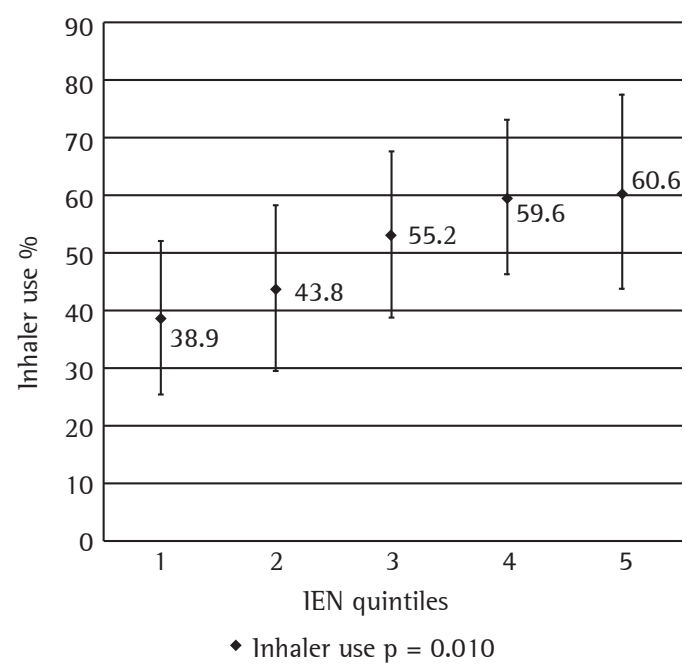

Figure 1 - Prevalence of inhaler use in those who reported symptoms in the previous year $(n=234)$, by Indicador Econômico Nacional (IEN, National Economic Indicator) quintile, Pelotas, Brazil, 2012. $p=0.01$, as assessed by the chi-square test for linear trend.
The prevalence of self-reported physiciandiagnosed asthma was investigated in adults (20 years of age or older) in studies conducted in the city of Pelotas in $2000^{(13)}$ and 2010.(14) However, the criteria used in those studies in order to define the outcome differ from those used in the present study, and it is therefore difficult to compare the studies in terms of the reported prevalence. The prevalence of self-reported asthma in the previous year has been reported to be $4.7 \%{ }^{(13)}$ and $5.2 \%{ }^{(14)}$ In the present study, by combining the questions regarding the diagnosis of asthma (no specific recollection period) and symptoms in the previous year, we found that $4.5 \%$ of those who were 20 years of age or older reported this condition. In addition, when analyzing that age group, we found significant differences between the genders in terms of the prevalence of asthma; this finding is consistent with those of previous studies, ${ }^{(13,14)}$ the prevalence of asthma being higher among females (7.1\% vs. $4.3 \% ; p=0.002$ ).

In individuals in the 10-19 year age bracket, the prevalence of asthma found in the present study was similar to that found in a study conducted in the city of Santa Maria, Brazil, i.e., 14.9\% for self-reported physician-diagnosed asthma ever; however, that study investigated individuals in the 13-14 year age bracket. ${ }^{(15)}$ Both proportions are superior to the $7.4 \%$ prevalence of self-reported

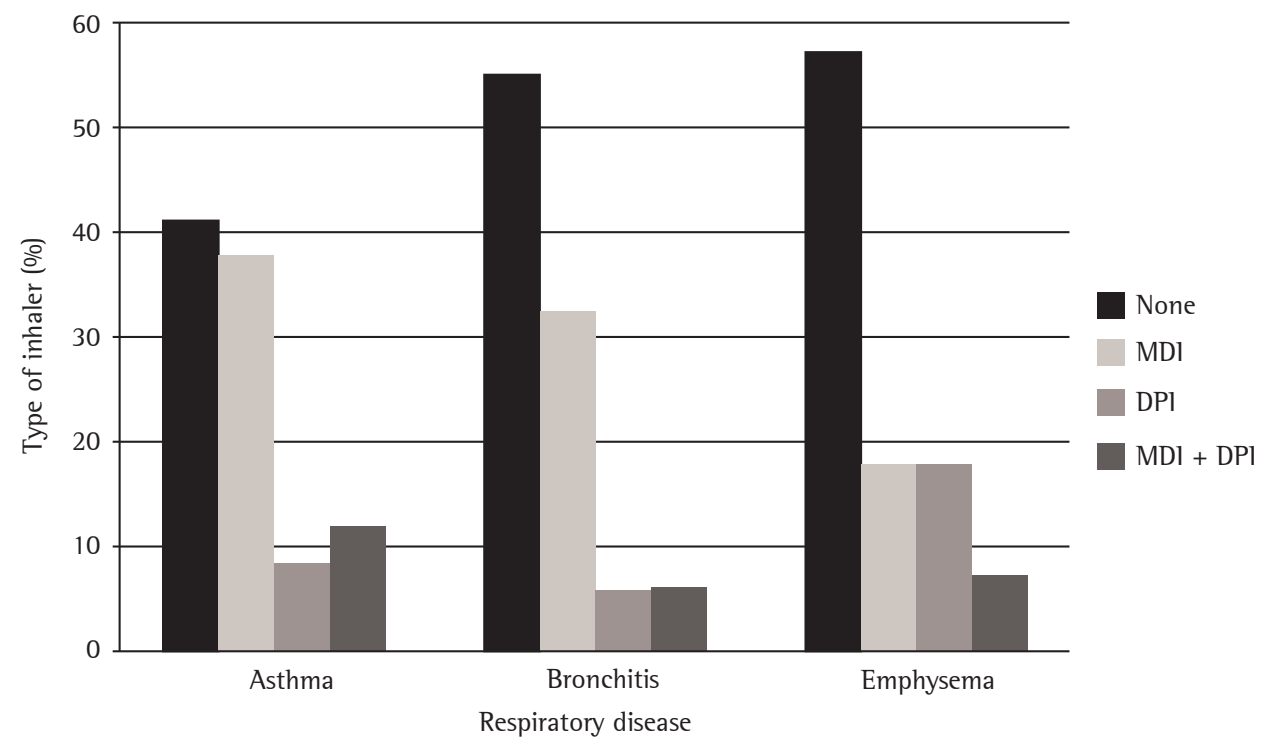

Figure 2 - Type of inhaler used in the previous year by those who reported symptoms in the previous year ( $n=235$ ), by self-reported diagnosis, Pelotas, Brazil, 2012. None: no inhaler use in the previous year; MDI: metered dose inhaler; and DPI: dry powder inhaler. 


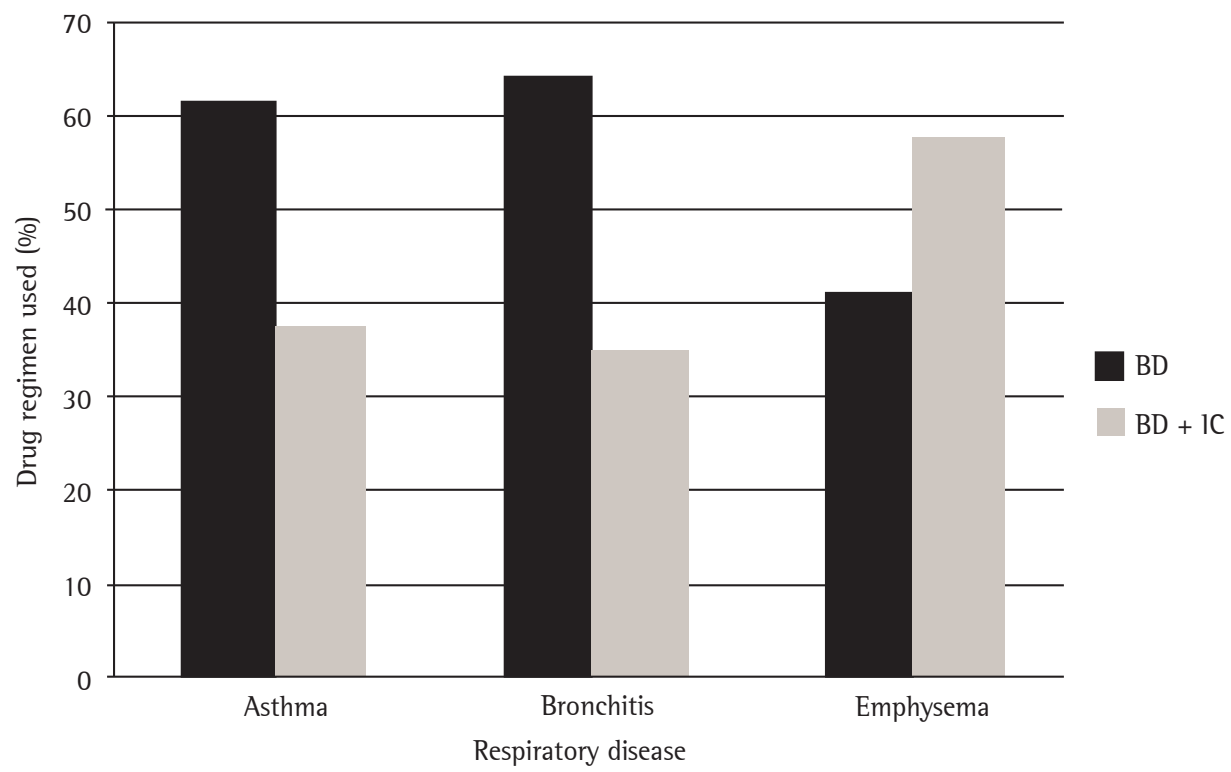

Figure 3 - Drug regimen used by those who reported symptoms in the previous year ( $n=118$ ), by selfreported diagnosis, Pelotas, Brazil, 2012. BD: bronchodilator; and IC: inhaled corticosteroid.

asthma found in individuals in the 10-19 year age bracket in southern Brazil in 2008. ${ }^{(16)}$

The questions regarding bronchitis and emphysema were asked only to adults (20 years of age or older) because COPD affects individuals over 40 years of age..$^{(2)}$ Because the term "bronchitis" is used by asthma and COPD patients alike, we believe that the prevalence found in the present study refers to both conditions. It is likely that the smokers or former smokers over 40 years of age reporting bronchitis have COPD. The proportion of individuals with self-reported bronchitis was highest among current smokers.

Regarding emphysema, data from the PLATINO ${ }^{(17)}$ showed that the prevalence of selfreported physician-diagnosed emphysema in the city of São Paulo, Brazil, in 2003 was 1.2\%. We found a higher prevalence in individuals 20 years of age or older (i.e., 1.6\%) and in those 40 years of age or older (i.e., 2.5\%), the latter age group being the target of the PLATINO.

We chose the terms "bronchitis" and "emphysema" because the population is more familiar with those terms than it is with the term "COPD". In the PLATINO, ${ }^{(17)}$ the prevalence of self-reported physician-diagnosed COPD was $0.8 \%$, whereas, in a study conducted in the city of São Paulo in the 2008-2009 period, ${ }^{(18)}$ the prevalence of COPD was $4.2 \%$, suggesting greater familiarity with the term.
Half of those who were expected to have used an inhaler (i.e., those with a self-reported diagnosis of respiratory disease and symptoms in the previous year) had. However, 38\% of those who reported no inhaler use reported nebulizer use; that is, $12 \%$ of the symptomatic individuals had not used any type of inhalation treatment. It is of note that nebulizer use has disadvantages in comparison with inhaler use, including the lack of standardization of the devices regarding the emission of aerosol particles, causing uncertainty regarding the inhaled dose ${ }^{(19)}$; nebulizer use is indicated only for those who do not adapt to the inhalation of a controlled dose, such as debilitated patients or those with cognitive deficits, who fail to use the medication, even with a spacer. ${ }^{(1)}$

Each type of inhaler device has its own particularities, and the choice of inhaler to be prescribed depends on factors such as personal preferences, cost-benefit ratio, and patient cognition..$^{(1,4,19)}$ Of the two types of inhalers, MDls are the most readily available in the public health care system, being the most widely used in the present study.

The main reason for not having used an inhaler was the belief that there was no need to use it. This finding might reflect treatment nonadherence in those patients. In a study ${ }^{(20)}$ evaluating the treatment of eight chronic diseases, only $16 \%$ of all asthma patients were considered to have 
adhered to treatment, that proportion being the lowest proportion of treatment adherence among the diseases investigated; COPD ranked third, 38\% of all COPD patients having adhered to treatment.

The lack of adherence to inhaler use has been attributed to factors such as difficulty using inhalers, little satisfaction with the benefits of inhaler use, fear of adverse effects, prolonged duration of use, periods of symptom remission, and drug costs. ${ }^{(21,22)}$

A significant number of individuals reported lack of physician recommendation as the reason for not using inhalers; this reflects a situation that is common in Brazil and other countries; that is, the medication is not prescribed as recommended in consensus guidelines. ${ }^{(1,2)}$

In a study conducted in the city of Porto Alegre, Brazil, ${ }^{(23)}$ the medical records of patients treated in a pulmonology department were analyzed. Approximately $68 \%$ of the patients had received treatment that was not in accordance with the recommendations in current guidelines, and 71\% of those patients had uncontrolled asthma that was not being treated with corticosteroids. In the USA, the medical records of asthma patients were investigated, and it was found that less than $40 \%$ of the patients had been prescribed short-acting $\beta_{2}$ agonists and that less than 10\% of the patients who used BDs daily had been prescribed $1 \mathrm{Cs}^{(24)}$; regarding COPD, 72\% of the patients with the disease had been prescribed at least one BD, and $64 \%$ of the patients with frequent exacerbations had been prescribed 1Cs. ${ }^{(25)}$

The individuals who, despite having reported symptoms, believed that there was no need to use an inhaler, those who reported that they feared side effects, and those who reported having difficulty using inhalers are a reflection of the need for educational activities emphasizing the importance of inhaler use.

Our analysis of the drug regimens used by the individuals in our study sample showed that the proportion of combination therapy (BD $+1 \mathrm{IC})$ users was highest among the individuals who reported having emphysema. The use of ICs in COPD patients is controversial. A recent systematic review highlighted that $1 \mathrm{Cs}$ should be used only in those with frequent exacerbations. ${ }^{(26)}$ According to the Global Initiative for Chronic Obstructive Lung Disease guidelines, 1Cs should be reserved for those belonging to high-risk groups. ${ }^{(2)}$ ln our study, we did not evaluate the frequency or type of symptoms that can lead to an estimation of the severity of COPD; however, data from a previous population-based study showed that those for whom 1Cs are indicated account for only approximately $1 \%$ of all COPD patients. ${ }^{(6)}$

It is of note that inhalers are underused among socioeconomically disadvantaged populations, despite the fact that those populations have been reported as being the most affected by chronic respiratory diseases.

When the present study was conducted, the public health care system was going through a transition phase regarding inhalers provided free of charge. At the beginning of data collection, inhalers were restricted to two types of medication delivered via MDls, and asthma patients with more severe disease had access to other inhalers. (7) In addition, the Brazilian Popular Pharmacy program $^{(27)}$ offered discounts of up to $90 \%$ on some of those drugs. As of June of 2012, certain types of inhalers had come to be provided free of charge under the program, ${ }^{(28)}$ and, more recently, after the end of our data collection, new drugs began to be provided free of charge in the public health care system, with the objective of improving the treatment of patients diagnosed with COPD. ${ }^{(29)}$ Such changes can soon translate to changes in the inhaler use scenario, expanding the possibilities at the time of prescription and improving treatment adherence.

In the evaluation of the association between low socioeconomic status and lower use of inhalers, mediators other than low income should be taken into account. The underuse of inhalers can also be due to other factors, such as the type of facility used, access to specialist consultations, and the quality of the information provided. Although no such data were collected in the present study, the abovementioned factors can influence inhaler use and therefore should be examined in future studies. Therefore, multiple factors can be addressed in the development of measures to benefit this population and reduce the numbers of emergency room visits and hospitalizations due to preventable causes. ${ }^{(30)}$

We conclude that inhaler use among individuals with self-reported physician-diagnosed asthma, bronchitis, emphysema, or any combination of the three is far from ideal, especially among those of lower socioeconomic status. A significant proportion of symptomatic individuals reported 
nebulizer use only; however, this type of drug administration should not be the first choice for most individuals. ${ }^{(1)}$ The type of inhaled medication recommended for individuals with emphysema also deserves attention because it does not seem to be in accordance with the recommendations. . $^{(2,26)}$ Finally, the implementation of new policies for the free distribution of these drugs will meet the needs identified in the present study, because although few individuals reported lack of financial resources to purchase an inhaler as the reason for not using an inhaler, inhaler use is lowest among those of lowest socioeconomic status.

\section{References}

1. Diretrizes da Sociedade Brasileira de Pneumologia e Tisiologia para o Manejo da Asma. J Bras Pneumol. 2012;38(Suppl 1):S1-S46.

2. Global Initiative for Chronic Obstructive Lung Disease [homepage on the Internet]. Bethesda: Global Initiative for Chronic Obstructive Lung Disease [updated 2011 Dec; cited 2012 Nov] Global Strategy for the Diagnosis, Management and Prevention of COPD, (GOLD) 2011. Available from: http://www.goldcopd.org/guidelinesglobal-strategy-for-diagnosis-management.html

3. Sociedade Brasileira de Pneumologia e Tisiologia [homepage on the Internet]. Brasília: Sociedade Brasileira de Pneumologia e Tisiologia [updated 2012 Jun; cited 2012 Nov]. DPOC e Saúde Pública - Atendendo as necessidades dos pacientes. [Adobe Acrobat document, 17p.]. Available from: http://www.sbpt.org.br/downloads/ arquivos/COM_DPOC/Relatorio_final_DPOC_Saude_ Publica_2012_SBPT.pdf

4. Fromer L, Goodwin E, Walsh J. Customizing inhaled therapy to meet the needs of COPD patients. Postgrad Med. 2010;122(2):83-93. http://dx.doi.org/10.3810/ pgm.2010.03.2125 PMid:20203459

5. Muchão FP, Perín SL, Rodrigues JC, Leone C, Silva Filho LV. Evaluation of the knowledge of health professionals at a pediatric hospital regarding the use of metered-dose inhalers. J Bras Pneumol. 2008;34(1):4-12. http://dx.doi. org/10.1590/S1806-37132008000100003 PMid:18278370

6. Menezes AM. Projeto Latino-Americano de Investigação em Obstrução Pulmonar. Montevideo: ALAT; 2007.

7. Dalcin Pde T, Grutcki DM, Laporte PP, Lima PB, Viana VP, Konzen GL, et al. Impact of a short-term educational intervention on adherence to asthma treatment and on asthma control. J Bras Pneumol. 2011;37(1):19-27. PMid:21390428

8. Smith MJ, Rascati KL, McWilliams BC. Inhaled antiinflammatory pharmacotherapy and subsequent hospitalizations and emergency department visits among patients with asthma in the Texas Medicaid program. Ann Allergy Asthma Immunol. 2004;92(1):40-6. http:// dx.doi.org/10.1016/S1081-1206(10)61708-5

9. Barros A, Menezes AM, Santos I, Assunção MC, Gigante D, Fassa AG, et al. 0 Mestrado do Programa de Pós-graduação em Epidemiologia da UFPel baseado em consórcio de pesquisa: uma experiência inovadora. Rev Bras Epidemiol. 2008;11(Suppl 1):133-44. http://dx.doi.org/10.1590/ S1415-790X2008000500014
10. Barros AJ, Victora CG. A nationwide wealth score based on the 2000 Brazilian demographic census [Article in Portuguese]. Rev Saude Publica. 2005;39(4):523-9. http://dx.doi.org/10.1590/S0034-89102005000400002 PMid:16113899

11. Portal ABEP [homepage on the Internet]. São Paulo: ABEP [cited 2012 Nov]. Critério de Classificação Econômica Brasil 2010. Available from: http://www.abep.org/novo/ Content.aspx?ContentID=301

12. Ernst P. Inhaled drug delivery: a practical guide to prescribing inhaler devices. Can Respir J. 1998;5(3):180-3. PMid:9707463

13. Macedo SE, Menezes AM, Knorst M, Dias-da-Costa JS, Gigante DP, Olinto MT, et al. Risk factors for asthma in adults in Pelotas, Rio Grande do Sul State, Brazil [Article in Portuguese]. Cad Saude Publica. 2007;23(4):863-74. http://dx.doi.org/10.1590/S0102-311X2007000400014 PMid: 17435884

14. Fiori NS, Gonçalves H, Dumith SC, Cesar MA, Menezes AM, Macedo SE. Ten-year trends in prevalence of asthma in adults in southern Brazil: comparison of two populationbased studies. Cad Saude Publica. 2012;28(1):135-44. PMid:22267073

15. Cassol VE, Rizzato TM, Teche SP, Basso DF, Hirakata VN, Maldonado M, et al. Prevalence and severity of asthma among adolescents and their relationship with the body mass index [Article in Portuguese]. J Pediatr (Rio J). 2005;81(4):305-9.

16. Wehrmeister FC, Menezes AM, Cascaes AM, MartínezMesa J, Barros AJ. Time trend of asthma in children and adolescents in Brazil, 1998-2008. Rev Saude Publica. 2012;46(2):242-50. http://dx.doi.org/10.1590/S003489102012005000008 PMid:22310651

17. Menezes AM, Jardim JR, Pérez-Padilla R, Camelier A, Rosa F, Nascimento O, et al. Prevalence of chronic obstructive pulmonary disease and associated factors: the PlATiNo Study in São Paulo, Brazil. Cad Saude Publica. 2005;21(5):1565-73. http://dx.doi.org/10.1590/ S0102-311X2005000500030 PMid:16158163

18. Sousa CA, César CL, Barros MB, Carandina L, Goldbaum M, Pereira JC. Prevalence of chronic obstructive pulmonary disease and risk factors in São Paulo, Brazil, 2008-2009. Rev Saude Publica. 2011;45(5):887-96. http://dx.doi. org/10.1590/S0034-89102011005000051 PMid:21808830

19. Melani AS. Inhalatory therapy training: a priority challenge for the physician. Acta Biomed. 2007;78(3):233-45. PMid:18330086

20. Priest JL, Cantrell CR, Fincham J, Cook CL, Burch SP. Quality of care associated with common chronic diseases in a 9-state Medicaid population utilizing claims data: an evaluation of medication and health care use and costs. Popul Health Manag. 2011;14(1):43-54. http:// dx.doi.org/10.1089/pop.2010.0019 PMid:21142926 PMCid:3128443

21. Santos Dde O, Martins MC, Cipriano SL, Pinto RM, Cukier A, Stelmach R. Pharmaceutical care for patients with persistent asthma: assessment of treatment compliance and use of inhaled medications. J Bras Pneumol. 2010;36(1):1422. PMid:20209303

22. Lareau SC, Yawn BP. Improving adherence with inhaler therapy in COPD. Int J Chron Obstruct Pulmon Dis. 2010;5:401-6. http://dx.doi.org/10.2147/COPD.S14715 PMid:21191434 PMCid:3008325

23. Mattos W, Grohs LB, Roque F, Ferreira M, Mânica G, Soares E. Asthma management in a public referral center in Porto 
Inhaler use in adolescents and adults with self-reported physician-diagnosed asthma,

Alegre in comparison with the guidelines established in the 111 Brazilian Consensus on Asthma Management. J Bras Pneumol. 2006;32(5):385-90. http://dx.doi.org/10.1590/ S1806-37132006000500003 PMid:17268740

24. Piecoro LT, Potoski M, Talbert JC, Doherty DE. Asthma prevalence, cost, and adherence with expert guidelines on the utilization of health care services and costs in a state Medicaid population. Health Serv Res. 2001;36(2):35771. PMid:11409817 PMCid:1089228

25. Diette GB, Orr P, McCormack MC, Gandy W, Hamar B. Is pharmacologic care of chronic obstructive pulmonary disease consistent with the guidelines? Popul Health Manag. 2010;13(1):21-6. http://dx.doi.org/10.1089/ pop.2008.0048 PMid:20158320

26. Menezes AM, Macedo SE, Noal RB, Fiterman J, Cukier A, Chatkin JM, et al. Pharmacological treatment of COPD. J Bras Pneumol. 2011;37(4):527-43. http://dx.doi. org/10.1590/S1806-37132011000400016 PMid:21881744

27. Ministério da Saúde [homepage on the Internet]. Brasilia: Ministério da Saúde [cited 2011 Sep 1]. Programa Farmácia
Popular do Brasil. Available from: http://portal.saude. gov.br/portal/saude/area.cfm?id_area $=1095$

28. Ministério da Saúde [homepage on the Internet]. Brasilia: Ministério da Saúde [updated 2012 May 1; cited 2012 Nov 1]. Farmácia Popular terá remédio de graça para asma. Available from: http://portalsaude.saude.gov.br/ portalsaude/noticia/5034/162/farmacia-popular-teraremedio-de-graca-para-asma.html

29. Ministério da Saúde [homepage on the Internet]. Brasília: Ministério da Saúde [updated 2012 Sep 1; cited 2012 Nov 1]. Medicamentos para doença pulmonar estarão no SUS. Available from: http://portalsaude.saude.gov. br/portalsaude/noticia/7358/162/medicamentos-paradoenca-pulmonar-estarao-no-sus.html

30. Dias-da-Costa JS, Borba LG, Pinho MN, Chatkin M. Quality of primary care as measured by preventable hospitalizations in the South of Brazil [Article in Portuguese]. Cad Saude Publica. 2008;24(7):1699-707. http://dx.doi.org/10.1590/ S0102-311X2008000700024 PMid:18670693

\section{About the authors}

Paula Duarte de Oliveira

Doctoral Student. Graduate Program in Epidemiology, Federal University of Pelotas, Pelotas, Brazil.

Ana Maria Baptista Menezes

Full Professor. Graduate Program in Epidemiology, Federal University of Pelotas, Pelotas, Brazil.

Andréa Dâmaso Bertoldi

Adjunct Professor. Graduate Program in Epidemiology, Federal University of Pelotas, Pelotas, Brazil.

Fernando César Wehrmeister

Adjunct Professor. Graduate Program in Epidemiology, Federal University of Pelotas, Pelotas, Brazil. 